DOI :10.31357/fapsmst.2004.00476

\title{
IMPACTS OF ANTHROPOGENIC ACTIVITIES ON THE WATER QUALITY AND FISH OF "MADOLA" STREAM GALLE
}

BY

K.G. RASIKA DHARMASRI

Thesis submitted to the University of Sri Jayewardenepura for the awarded of the Degree of Master of Science in Fisheries and Aquatic Resource Development on 2004. 


\section{Declaration by the Candidate}

The work described in this thesis was carried out by me under the supervision of Dr (Mrs.)

N.J. De S. Amarasinghe and a report on this has not been submitted in whole or in part to any university for another Degree/Diploma.

Name : $\quad$ K.G. Rasika Dharmasri

Signature:

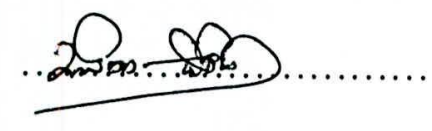

Date : (..22..0.7:.2.945......

\section{Declaration by the Supervisor}

I certify that the above statement made by the candidate its true and this thesis is suitable for submission to the university for the purpose of evaluation.

Name : Dr. N.J. De S. Amarasinghe

Signature: $\quad$......

Date : $\quad$ (.28.: $0.7 .20 .0 .5 \ldots \ldots \ldots$ 


\section{List of Contents}

Acknowledgements

Page

List of Tables

i

List of Figures

Abstract

Chapter 1 - Introduction

Chapter 2 - Materials and Methods

iii

V

vii

1

2.1 Study area

8

8

2.1.1 Sampling sites 10

2.2 Methodology 13

2.2.1 Physico Chemical Parameters

14

2.2.2 Fish Fauna in the stream

2.2.3 Benthos in the stream

2.2.4 Planktons in the stream

2.2.5 Anthropogenic impacts

Chapter 3 - Results

3.1 Physico Chemical parameters

3.2 Fish fauna in Madola

3.3 Benthos in Madola

3.4 Planktons in Madola

3.5 Anthropogenic impacts

Chapter 4 - Discussion

Chapter 5 - Conclusion

Reference

70

Appendix 


\section{Acknowledgements}

First of all I take this opportunity to thank Prof. J Jinadasa, Department of Zoology, University of Sri Jayewardenepura for giving me an opportunity to carryout this research project.

I don't know how to thank Dr. (Mrs.) N. J. De S Amarasinghe, Fomer Head of the Zoology Department, University of Ruhuna for her support. As a supervisor she provided me laboratory facilities, valuable guidance, stimulating discussions and encouragement throughout this research work.

My special thanks should be given to Dr. (Mrs.) Ajantha De Alwis, Department of Zoology, University of Sri Jayewardenepura who was the coordinator of the Masters Degree Programme. She gave me guidance and moral support through out this work to make it a success.

I extend my deepest gratitude to Dr. W.A.H.P. Guruge, Senior Lecturer, Department of Zoology, University of Ruhuna for his support in the laboratory and analyzing the data.

I would like to thank the laboratory staff of the Zoology Department, University of Ruhuna for their field and laboratory assistance. 
I am grateful to the officers of Ginganga Project, Irrigation Engineer's Office, Indigasketiya, Baddegama, Galle and Divisional Secretariat Office of Akmeemana and Bopepodala.

I am sure this research could have not been done without the support of the villagers of Hiyare, Ihalagoda, Totagoda and Holuwagoda. They are gratefully acknowledged.

My dear friends Chandima, Priyankara Lal, Imalka, Pushpakumara also extended their support throughout this work.

I wish to express my sincere thanks to Mrs. A.B.K. Chithra and Mrs. Jayani Wickramaarachchi and Kavindu Soysa for their cooperation in typing this report.

My thanks and apologies to others whom I may have forgotten to mention.

Finally, I have to say all the criticisms were most valuable but the errors that remain are mine. 


\section{List of Tables}

\section{Table}

(1) Mean width and Mean depth at each site

(2) Mean values of physico chemical parameters

(3) Correlation between some physico chemical parameters in each site

(4) List of fish families and species recorded in Madola

(5) Status of different fish species in Madola

(6) List of the fish species only at one site during the study 41

(7) Recorded benthos in Madola

(8) Status and abundance of fish recorded in each site

(9) (a) Shannon Weaver Diversity Index Values for fish species in site A

(b) Shannon Weaver Diversity Index Values for fish species in site B

(c) Shannon Weaver Diversity Index Values for fish species in site C

(d) Shannon Weaver Diversity Index Values for fish species in site D

$(10-a)$ habitat preference of benthos in each site

b) Habitat preference of benthos in each substrate

(11-a) Shannon Weaver Diversity Index Values for benthos in different sites A 81

b) Shannon Weaver Diversity Index Values for benthos in different sites B 82

c) Shannon Weaver Diversity Index Values for benthos in different sites C 83

d) Shannon Weaver Diversity Index Values for benthos in different sites D 84 
(12- a) Shannon Weaver Diversity Index Values for benthos

in different substrates types - leaf

b) Shannon Weaver Diversity Index Values for benthos

in different substrates types - mud

c) Shannon Weaver Diversity Index Values for benthos

in different substrates types - sand

d) Shannon Weaver Diversity Index Value for benthos

in different substrates types - stone

(13) Anthropogenic activities - Results given by the questioner 


\section{List of Figures}

\section{Figures}

(1) Location of the study area 9

(2-a) Study sites - site A and B 11

b) Study sites - site C and D 12

(3) Mean values of secchi disk visibility and Flow rate 21

(4) Relationship between flow rate and distance 22

(5-a) Monthly variation of mean air temperatures and

water temperatures in Madola

b) Temperature variations in each site of Madola 23

(6) DO and BOD variations in each site 24

(7) $\mathrm{P}^{\mathrm{H}}$ variation in each site 25

(8) conductivity variation in each site 26

$\begin{array}{ll}\text { (9) Salinity variation in each site } & 27\end{array}$

(10) $\mathrm{NO}_{3}{ }^{-}, \mathrm{PO}_{4}^{-3}$ and Total Alkalinity variation in each site 27

(11) Variation of $\mathrm{NH}_{3}$ in each sites 28

(12) Variation of suspended matters in each site 29

(13) Species Diversity of fish 33

(14-a) \% of the status of fish species recorded in Madola 35

b) status of fish species at different site $\quad 35$

(15) Variation of total no. of fish and total no. of species in each site 36

(16) Variation of abundance of different fish species in madola 37 
(17) Variation of abundance of fish fauna at different locations - a and b 38 c and d $\quad 39$

(18) Some fish species found in Madola 42

(19) Abundance of benthic fauna in different locations 44

(20) Composition of different taxonomic group in Madola 44

(21) Benthic diversity in each site of Madola 45

(22) Number of benthos in each substrate 46

(23) Substrate preference of benthos in the stream 47

(24) Substrate preference of benthic fauna in Madola 47

(25) Benthic diversity in each substrate 49

(25-a) Representatives of some benthic fauna in Madola 49

-b) Representatives of some benthic fauna in Madola $\quad 50$

(26-a) Abundance of planktons in each site $\quad 52$

b) Representatives of some planktons in Madola 53

(27) Use of water for livelihood 54

(28) Use of water for livelihood in different locations 55

(29) Water use for washing 56

(30) Water use for washing in different locations 56

(31) Adding pesticides or fertilizers for agriculture in different sites 57 


\title{
Impacts of anthropogenic activities on the water quality \\ and fish of Madola stream Galle
}

\section{K. G. Rasika Dharma sri}

\begin{abstract}
Hiyare reservoir was built in close proximity to the Galle Town to supply water to the town area. The excess water of the reservoir has created the stream Madola which drains through Akmeemana and Bope-Poddala AGA divisions for a length of about twelve miles before it joins the Ginganga at Holuwagoda.
\end{abstract}

Physico-chemical and biological parameters at four selected locations and the anthropogenic impacts were studies for a period of six months from June to November 2003.

The mean values of different physico-chemical parameters recorded during the study period in Madola stream were, as follows: $\quad$ Depth $=0.85 \mathrm{~m}$; width $=9.23 \mathrm{~m}$; secchi disk visibility $=0.73 \mathrm{~m}$; Flow rate $=0.0134 \mathrm{~m} / \mathrm{s}$; water temperature $=27.9 \mathrm{C}^{0} ;$ DO $=$ $7.02 \mathrm{mg} / l ; \quad B O D=1.50 \mathrm{mg} / \mathrm{l} ; \mathrm{P}^{\mathrm{H}}=7.67 ;$ Salinity $=2.46 \% ; \mathrm{PO}_{4}{ }^{-3}=0.0592 \mathrm{mg} / l ; \mathrm{NO}_{3}{ }^{-}=$ $0.53 \mathrm{mg} / l ; \quad$ Alkalinity $=0.124 \mathrm{Meq} / l ; \mathrm{NH}_{3}=0.005 \mathrm{mg} / l ; \quad$ Conductivity $=073 \mu \mathrm{s} ;$ Suspended matters $=9.6 \mathrm{mg} / 1$.

Thirty fish species were recoded in this study and most of the species belonged to the family cyprinidae.

Out of the total number of fish species, $60 \%$ were contributed by indigenous fish, $30 \%$ by endemic while $10 \%$ by exotic fish.

The highest species diversity was recorded at sire $\mathrm{C}$ while the lowest was at site $\mathrm{B}$. The highest abundance was recorded at site B while the lowest at site D.

vii 
The most dominant fish species at Madola were Puntius filamentosus, Rasbora daniconius, Danio malabaricus and Puntius nigrofasciatus.

The benthos of the Madola stream comprised of three families of oligochaeta (Lumbricidae, Tubificidae, Naididae), three families of gastropodes (Neritidae, Thiaridae, Vivaparidae), three families of crustaceans (Atyidae, Palaemonidae, potamonidae) and seventeen families of insects.

However the composition of benthos varied at different locations indicating their preference for different substrate types and water quality parameters.

The zooplankton community was represented by the rotifers, crustaceans such as cloadocerance, copepods and immature stages of insects such as mosquitoes, may flies, chironomids, stoneflies and dragon flies.

The inhabitants of the study area used water for drinking, bathing, washing, agriculture and for fishing.

Use of pesticide was identified as the main source of pollution indicating the most important anthropogenic impact on the stream ecosystem. 


\section{CHAPTER 1}

\section{Introduction}

The fresh water which is considered as the essence of life is becoming a " non-renewable resource" in reality due to anthropogenic activities, although it is a renewable resource in nature. In recognizing this issue, the year 2003 was declared as the international year of fresh water by the United Nations Organization.

Sri Lanka has 103 distinct natural river basins that cover over $90 \%$ of the island. Their catchment areas range from $9-10327 \mathrm{sq} \mathrm{km}$ and 18 river basins have catchment areas of more than 1000sq km. The 9 major rivers and 94 smaller rivers that drain Sri Lanka have a total collective length of around 4560 kilometers (Arumugam, 1969).

Several streams and tributaries join to form rivers. These fresh water habitats differ from size, depth, rate of water flow, type of bottom and so on (Fernando, 1990).

Pethiyagoda (1991) illustrated the fresh water fish fauna of Sri Lanka. He listed a total number of 108 species including 62 fresh water dispersant, 26 salt water dispersant and 20 exotic species. According to custom reports about 65 species (out of a total of 108 species) of fresh water fishes are being exported including at least 24 endemic species (out of the total of 27endemic species) amongst those that have restricted ranges. The exploitation of 
natural populations for export as part of aquarium fish trade has been identified as a major threat to endemic fish fauna (Amarasinghe, 1995).

Micro habitats overlap within habitats and these micro habitats of fishes are very important to determine their distribution pattern. Co-occuring species were less particularly in relation to their position in water column. Analysis of habitat use and dietary requirements revealed that most fish species in the assemblages were segregated on the basis of micro habitats and food regardless of the origin of the fish (Wickramanayake and Moyle, 1989).

See and Zoetemyer (1987) carried out an integrated study on the distribution and habitats of cyprinids in the lowlands of south western Sri Lanka. His results revealed that for most species that occur together in the same water type, large overlaps were found for both horizontal and vertical position.

Many benthic invertebrates act as pollution indicator organisms. Apart from sampling the water for specific chemical pollutants, examination of natural aquatic biota, can give a good overall indication of water quality. It is better and rapid indicators of the long term integrated effects of multiple water quality factors. Fresh water depteran larvae and oligocheate worms are good examples for pollution indicators. The colonization of these animals on surfaces can show the integrated effects of water quality on diversity, abundance, growth and mortality of many common fouling organisms (Stirling, 1985). 
Planktons are important component of aquatic systems. These organisms also serve as indicators of water quality. Chemical conditions play an important role in determining the taxonomic nature of the plankton. Species composition is used to classify whether the water is polluted or not and it indicates the quantities of various naturally occurring substances such as Nitrogen and Phosphorous.

Abiotic factors vary in intensity from place to place. Individual species display individual sets of tolerance ranges to various abiotic factors and it can be predicted that these will be reflected in their differential distribution patterns. Physico chemical factors such as Dissolved Oxygen, Biochemical Oxygen Demand, $\mathrm{PH}$ temperature and turbidity are frequently used to determined the water quality. $\mathrm{P}^{\mathrm{H}}$, DO, BOD, suspended solids, $\mathrm{NH}_{3}$, $\mathrm{NO}_{3}{ }^{-}$are most important factors because they are closely correlated with stress and incidence of diseases. (Townsend, 1980).

Simple observations of water colour, secchi depth/transparency, in the absence of high inorganic turbidity are also good indicators for prevailing nutrients levels and water quality (Stirling, 1985).

The quality of water in which many fresh water fishes of Sri Lanka occur are listed and discussed by Costa and Starmuhlner (1972), Costa (1980), Radda (1973) and Weinger (1972). The water of streams is usually slightly acidic. $\left(\mathrm{P}^{\mathrm{H}}=5.8-6.4\right)$, Soft $(0.25-1.5$ $\left.\mathrm{DH}^{\circ}\right)$, Cool $\left(20^{\circ} \mathrm{c}-25^{\circ} \mathrm{c}\right.$ in day time $)$ and very clear. These conditions vary when it reaches to the down stream where the agricultural pollutants are added. Geisler (1967) paidhis 
attention to the water of south western forests. From here he found the range of hardness is $0.19-1.07 \mathrm{DH}^{\mathrm{o}}$ and $\mathrm{P}^{\mathrm{H}}$ range is $6.17-6.68$.

The streams flow through densely populated and intensively urbanized areas. Normally natural streams are modified mainly for infrastructure development and flood control when they flow through urbanized areas. These streams influence mainly on human activities, due to deteriorated water quality and biotic factors. The place where the water is stagnant, is a unique area for mosquitoes. Dengue, filariasis, malaria etc... can be spread in these areas.

Streams can receive vast amounts of organic and inorganic effluents from hospitals, factories, service stations, garages, houses, shops, markets, laundries and farms.

The quality of Sri Lankan surface water has been affected by irrigation related water shed management, deforestation, cultivation of crops and various types of human wastes. As water related problems in the country eutrophication, salination, feacal contamination, siltation and contamination with organic residues and trace metals are identified. Unfortunately the magnitude of deterioration of water quality and the subsequent effects on biotic and abiotic components of aquatic ecosystems and its direct or indirect effects on human health are hitherto unknown (Silva, 1996)

Our fresh water fish species are threatened due to several factors. So this is the high time to protect our endemic fish fauna for future generation. Introduction of exotic species may 